
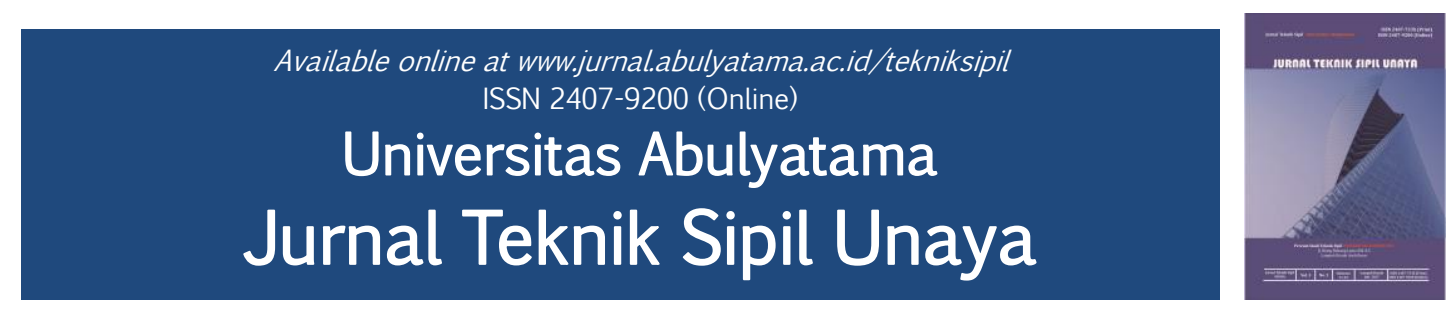

\title{
Identifikasi Kerusakan Dinding Penahan Tanah Sungai Siak (Studi Kasus Kecamatan Tualang Kabupaten Siak)
}

\author{
Fitridawati Soehardi $^{1^{*}}$, Marta Dinata ${ }^{2}$ \\ ${ }^{1}$ Program Studi Teknik Sipil, Fakultas Teknik, Universitas Lancang Kuning, Jl. Yos Sudarso \\ Km 8 Rumbai-Pekanbaru, 28265, Indonesia. \\ 2 Program Pendidikan Biologi, Fakultas Keguruan dan Ilmu Pendidikan, Universitas \\ Lancang Kuning, Jl. Yos Sudarso Km 8 Rumbai-Pekanbaru, 28265, Indonesia. \\ *Email korespondensi : fitridawati@unilak.ac.id.
}

Diterima 2 Mei 2018; Disetujui 2 Juli 2018; Dipublikasi 31 Juli 2018

\begin{abstract}
This study aims to identify the problem of damage to retaining walls on the banks of the Siak River, Tualang District, Siak District. The implementation of this research uses the method of direct observation in the field and the method of direct interviews with the community around the research location. The results of the data obtained are presented in the form of images of damage to the retaining wall. Conditions of Siak River Displacement, Tualang District, Siak Regency Shows a high level of damage both on the banks of natural rivers and those that have been given cliff protection. Some locations experience abrasion and erosion processes, especially in areas that are still natural. Damage to Siak Riverbanks is caused by natural factors and anthropogenic factors. Natural factors can be strong currents and waves caused by community transportation activities and factories around the Siak River environment. So that it can result in abrasion, damage to ecosystems, and damage to cliff safety buildings. While the Anthropogenic Factor is the behaviour of the community and the factory around Sungai Siak which does not comply with regional regulations and the applicable rules.
\end{abstract}

Keywords: Damage, Retaining wall, Erosion.

\begin{abstract}
Abstrak: Penelitian ini bertujuan untuk mengidentifikasi permasalahan kerusakan pada dinding penahan tanah yang ada di bantaran sungai siak Kecamatan Tualang Kabupaten siak. Pelaksanaan penelitian ini menggunakan Metode pengamatan langsung dilapangan dan metode wawancara langsung pada masyarakat sekitar lokasi penelitian. Hasil data yang diperoleh di sajikan dalam bentuk gambar kerusakan pada dinding penahan tanah. Kondisi Bantaran Sungai Siak Kecamatan Tualang Kabupaten Siak Menunjukkan tingkat Kerusakan yang cukup tinggi baik pada bantaran sungai yang alami maupun yang telah diberikan pengaman tebing. Beberapa lokasi mengalami proses abrasi dan erosi terutama pada daerah yang masih alami.Kerusakan Bantaran Sungai siak diakibatkan oleh faktor alam dan faktor antropogenik. Faktor alami dapat berupa kuat arus dan gelombang yang diakibatkan oleh aktifitas trasportasi masyarakatdan pabrik di sekitar lingkungan Sungai Siak. Sehingga dapat mengakibatkan abrasi, kerusakan ekosistem, dan kerusakan bangunan pengaman tebing. Sedangkan Faktor Antropogenik dalah perilakuk masyarakat dan Pabrik disekitar Sungai siak yang tidak memetuhi peraturan daerah dan kaidah yang berlaku.
\end{abstract}

Kata kunci : Kerusakan, dinding Penahan Tanah, Erosi. 
Sungai Siak merupakan sungai terdalam yang ada di Indonesia yang memiliki karakteristik unik. Sungai ini panjangnya mencapai $\pm 345 \mathrm{~km}$ dengan debit aliran berkisar antara 594-7859 m3/detik (antara tahun 19811992). Panjang Sungai Siak yang dapat dilayari mencapai $200 \mathrm{Km}$. Lebar Sungai Siak bervariasi dari 20-200 $\mathrm{m}$ dan kedalaman antara 6-26 m, dengan penampang dasar berbentuk V. Saat ini debit minimum Sungai Siak sekitar 45 m3/ detik dan debit maksimum rata-rata $1700 \mathrm{~m} 3 /$ detik, sedangkan debit normal sebesar $200 \mathrm{~m} 3 /$ detik. Rasio debit musim kemarau terhadap debit musim hujan dari waktu ke waktu menunjukkan peningkatan, karena semakin rusaknya daerah tangkapan air yang disebabkan oleh tingginya alih guna lahan hutan menjadi lahan perkebunan. Perubahan fungsi hidro-orologis tersebut akhirnya mengakibatkan kurang idealnya pola ketersediaan air (Iskandar.dkk,2012).

Sungai siak merupakan salah satu sungai terbesar di Provinsi Riau dan mempunyai peranan penting dalam kehidupan masyarakatnya. Sungai Siak dipergunakan sebagai sarana trasportasi barang maupun penumpang bagi masyarakat dan perusahaan sekitar dalam mengangkut bahan baku dan hasil produksi dan jalur yang menghubungkan antara kota pekanbaru, kabupaten siak dan Kabupaten lainnya. Akibat aktifitas transportasi tersebut menimbulkan terjadinya erosi pada tebing sungai siak dan mengalami penurunan fungsi kualitas air.

Perkembangan yang pesat di DAS Siak, membuat DAS Siak semakin kritis. Di DAS Siak terdapat 47 kegiatan pabrik dan penambangan minyak bumi skala besar. Kunjungan kapal di dermaga sepanjang Sungai Siak untuk kepentingan sendiri tahun 200 sebanyak 10.450 buah (Zainal, 2005). menurut Wahana Lingkungan Hidup Indonesia (WALHI), sungai siak saat ini telah mengalami abrasi sepanjang satu meter setiap tahunnya pada masing-masing kedua bibir sungai siak. Sedimentasi dan pedangkalan akibat berbagai faktor termasuk abrasi pada sungai siak terjadi sangat signifikan.(Antaranews.com,2017).

Salah satu akibat dari pengelolaan DAS dan pengaturan lahan yang tidak dilakukan secara benar dan tidak terencana dengan baik, dapat mempengaruhi proses terjadinya erosi. Erosi adalah proses terkikisnya dan terangkutnya tanah atau bagian-bagian tanah oleh media alami yang berupa air. Erosi dapat mempengaruhi produktivitas lahan yang biasanya mendominasi DAS bagian hulu dan dapat memberikan dampak negatif pada DAS bagian hilir (sekitar muara sungai) yang berupa hasil sedimen(Anwar.dkk, 2009).

Upaya dalam melindungi bantaran sungai salah satunya adalah dengan membangun dinding penahan tanah hal ini diperlukan untuk mempertahankan kondisi bantaran sungai dari proses terjadinya erosi. Selain itu dapat menambah estetika, dengan menambah keindahan bantaran sungai mampu mendorong peranserta masyarakat dalam mejaga kebersihan dan keindahan sumber daya air sungai siak dengan tidak membangun perumahan dibantaran sungai dan tidak membuang sampah ke sungai 
(Rosihun2011),. Pemerintah kabupaten siak memiliki komitmen menyelamatkan Sungai Siak antara lain membangunan infrastruktur pengaman tebing di sepanjang bantaran Sungai Siak baik berupa turap, bronjong dan lainnya, dengan konsep "water Front City" dan melakukan relokasi daerah pemukiman kumuh dibantaran sungai Siak, melakukan penghijauan di sepanjang bantaran sungai (infosiak.com,2017).

Berdasarkan pengamatan dilapangan studi kasus di kecamatan Tualang Kabupaten Siak, kondisi tanah dan dinding pengaman tebing disepanjang bantaran sungai siak mengalami perubahan dan penurunan fungsi bangunan, sehingga perlu dilakukan penelitian dengan melakukan identifikasi terhadap kerusakan kerusakan pada dinding pengaman tebing.

\section{KAJIAN PUSTAKA}

\section{Sungai}

Berdasarkan Peraturan Pemerintah Nomor 35 Tahun 1991, sungai adalah tempat-tempat dan wadah-wadah serta jaringan pengaliran air mulai dari mata air sampai muara dengan dibatasi pada kanan kirinya serta sepanjang pengalirannya oleh garis sempadan(Naditia,2011).

\section{Daerah Aliran Sungai (DAS)}

Daerah Aliran Sungai (DAS) adalah suatu wilayah ekosistem yang sangat berperan dalam masalah lingkungan. Ekosistem ini dibatasi oleh igir-igir punggung bukit (river divide dan berfungsi sebagai pengumpul, penyimpan, dan penyalur air, sedimen serta unsur-unsur hara dalam sistem sungai, dan keluar dari wilayah tersebut melalui satu titik tunggal (single outlet). Daratan atau pulau hampir seluruhnya terbagi dalam satuan daerah aliran sungai (DAS). Di DAS ada rangkaian. proses pengumpulan, penyimpanan, penambatan dan penyaluran air, yang semuanya itu menjadi suatu sistem hidrologis dan memiliki peran yang sangat penting dalam pengaturan tata air( Lihawa,dkk, 2014).

\section{Erosi Tebing sungai}

Erosi Tebing sungai adalah pengikisan tanah pada tebing-tebing sungai dan penggerusan dasar sungai oleh aliran sungai. Dua proses berlangsungnya erosi tebing sungai adalah oleh adanya gerusan aliran sungai dan oleh adanya longsoran tanah pada tebing sungai. Semakin cepat laju aliran sungai (debit puncak atau banjir) semakin besar kemungkinan terjadinya erosi tebing. Erosi tebing sungai dalam bentuk gerusan dapat berubah menjadi tanah longsor ketika permukaan sungai surut (meningkatkan gaya tarik kebawah) sementara pada saat bersamaan tanah tebing sungai telah jenuh. Dengan demikian, longsoran tebing sungai terjadi setelah debit aliran besar berakhir dan surut. Proses terjadinya erosi tebing yang kedua lebih ditentukan oleh keadan kelembaban tanah di tebing sungai menjelang terjadinya erosi. Erosi tebing sungai dipengaruhi, antara lain oleh kecepatan aliran, kondisi vegetasi disepanjang tebing sungai, kegiatan bercocok tanam dipinggiran sungai, kedalaman dan lebar sungai, bentuk alur sungai dan tekstur 
sungai(Asdak,2007).

Faktor-faktor yang mempengaruhi erosi meliputi hujan, angin, limpasan permukaan, jenis tanah, kemiringan lereng, penutup lahan,dan tindakan konservasi. Faktor-faktor tersebut mempengaruhi erosi yang sebetulnya tidak dapat dipisahkan satu dengan yang lainya, artinya bekerja secara simultan. Semua faktor-faktor tersebut dapat digolongkan kedalam tiga kelompok yaitu: 1)energi merupakan kemampuan potensial hujan, limpasan permukaan atau angin dapat menyebabkan erosi, kemampuan tersebut yaitu erosivitas, 2) Kepekaan tanah yang begantung kepada sifat fisik dan kimia tanah, kemampuan tersebut yaitu erodibilitas, 3) proteksi yaitu bertitik tolak kepada faktorfaktor yang berhubungan dengan penutup lahan(Rahim,2000).

\section{Vegetasi}

Analisis vegetasi adalah cara mempelajari susunan komposisi spesiesdan bentuk strukturvegetasi atau masyarakat tumbuhtumbuhan. Dalam ekologi hutan satuan yang diamati adalah suatu tegakan, yang merupakan asosiasi konkrit. Analisis vegetasi adalah cara mempelajari susunan komposisi spesies dan bentuk struktur vegetasi atau masyarakat tumbuh-tumbuhan. Untuk suatu kondisi hutan yang luas, maka kegiatan analisa vegetasi erat kaitannya dengan contoh, artinya kita cukup menempatkan beberapa petak contoh untuk mewakili habitat tersebut. Dalam contoh ini ada tiga hal yang perlu diperhatikan, yaitu jumlah petak contoh, cara peletakan petak contoh dan teknik analisa vegetasi yang digunakan. Keragaman spesies merupakan ciri tingkat komunit berdasarkan organisasi biologinya. Keragaman spesies dapat digunakan untuk menyatakan struktur komunitas. Keragaman spesies juga dapat digunakan untuk mengukur stablitas komunitas, yaitu kemampuan suatu komunitas untuk menjaga dirinya tetap stabil meskipun ada gangguan terhadap komponenkomponennya. Salah satu upaya untuk mengidentifikasi tanaman adalah dengan melakukan pengujian herbarium. Spesimen herbarium dapat menghasilkan data yang lebih unik dan murah bila dibandingkan dengan penggunaan metode yang konvensional(Beauvais,dkk,2017).

\section{Dinding penahan tanah}

Dinding penahan tanah adalah suatu konstruksi penahan agar tanah tidak longsor. Konstruksi ini digunakan untuk suatu tebing yang agak curam / tegak dimana kemantapannya tidak dapat dijamin tanpa dinding penahan, tebing tersebut akan longsor. Dinding penahan tanah juga digunakan bila suatu jalan dibangun berbatasan dengan sungai, danau (Gholo,2014).

Dinding penahan tanah yang digunakan harus stabil terhadap pergeseran, penggulingan, dan keruntuhan kapasitas daya dukung tanah. Nilai faktor aman terhadap penggulingan $>1,5$, terhadap pergeseran $>1,5$, dan terhadap keruntuhan kapasitas daya dukung >3(Ramdhani,2010). 
METODE PENELITIAN

Ruang Lingkup Penelitian

Penelitian inidilakukan di sepanjang bantaran sungai Siang Kecamatan Tualang
Kabupaten Siak. Pengamatan dilakukan secara langsung dengan menyusuri aliran sungai Siak Kevamatan Tualang Kabupaten siak menggunakan kapal.

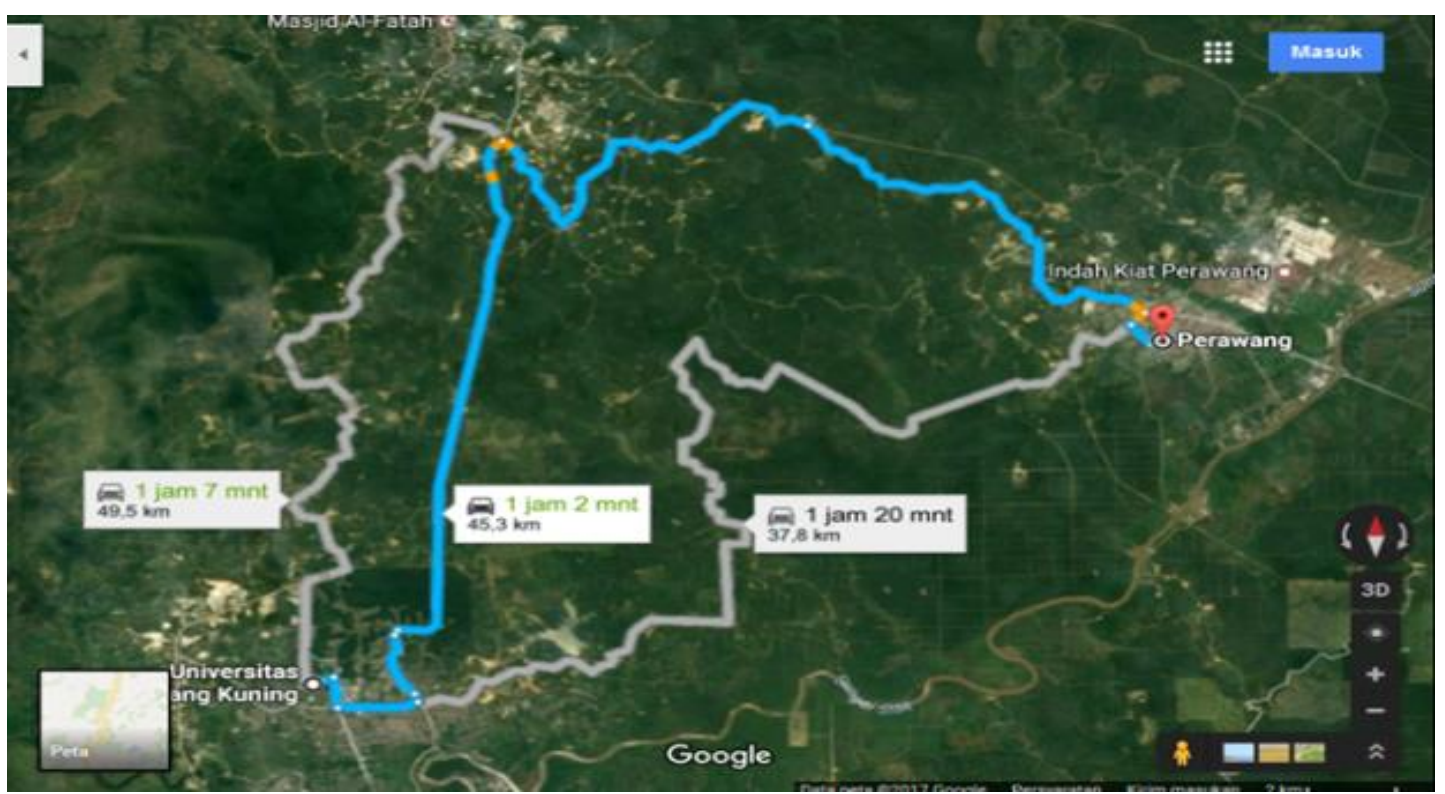

Gambar 1. Lokasi Penelitian

Data

Pengambilan Data dilakukkan selama hampir 2 ( Dua ) Bulan yakni pada bulan Maret dan April dengan menyusuri aliran sungai siak Kecamatan Tualang kabupaten siak menggunakan GPS MA,Foto Digital, Video Camera dan menggunakan metode wawancara secara langsung dengan masyarakat yang ada di sepanjang bantaran sungai siak kecamatan Tualang Kabupaten Siak. Hasil Pengamatan Ini didukung dengan data sekunder berdasarkan hasil penelitian sebelumnya, data curah hujan, dan data-data pendukung lainnya yang diperoleh dari instansi-instansi terkait.

\section{Pengolahan Data}

Data yang diperoleh dari lapangan kemudaian dianalisis agar dapat mengidentifikasi kerusakan dinding pengaman tebing serta Identifikasi Kerusakan Dinding ....

(Soehardi \& Dinata, 2018) bantaran sungai siak dengan menggunakan kajian - kajian penelitian sebelumnya, dan ditampilkan dalam bentuk gambar kondisi kerusakan bataran sungai dan Dinding Pengaman Tebing Yang mengalami kerusakan.

\section{HASIL DAN PEMBAHASAN}

\section{Proses Erosi Bantaran Sungai Siak}

Menurut Asdak Erosi Tebing sungai merupakan proses pengikisan tanah pada tebingtebing sungai dan penggerusan dasar sungai oleh aliran sungai. Ada dua faktor yang mempengaruhi proses berlangsungnya erosi tebing sungai adalah oleh adanya gerusan aliran sungai dan oleh adanya longsoran tanah pada tebing sungai.

Berdasarkan pengamatan dilapangan diketahui bahwa bantaran sungai siak mengalami 
pengikisan tanah pada tebing -tebing sungai seperti yang dapat dilihat pada gambar 2.
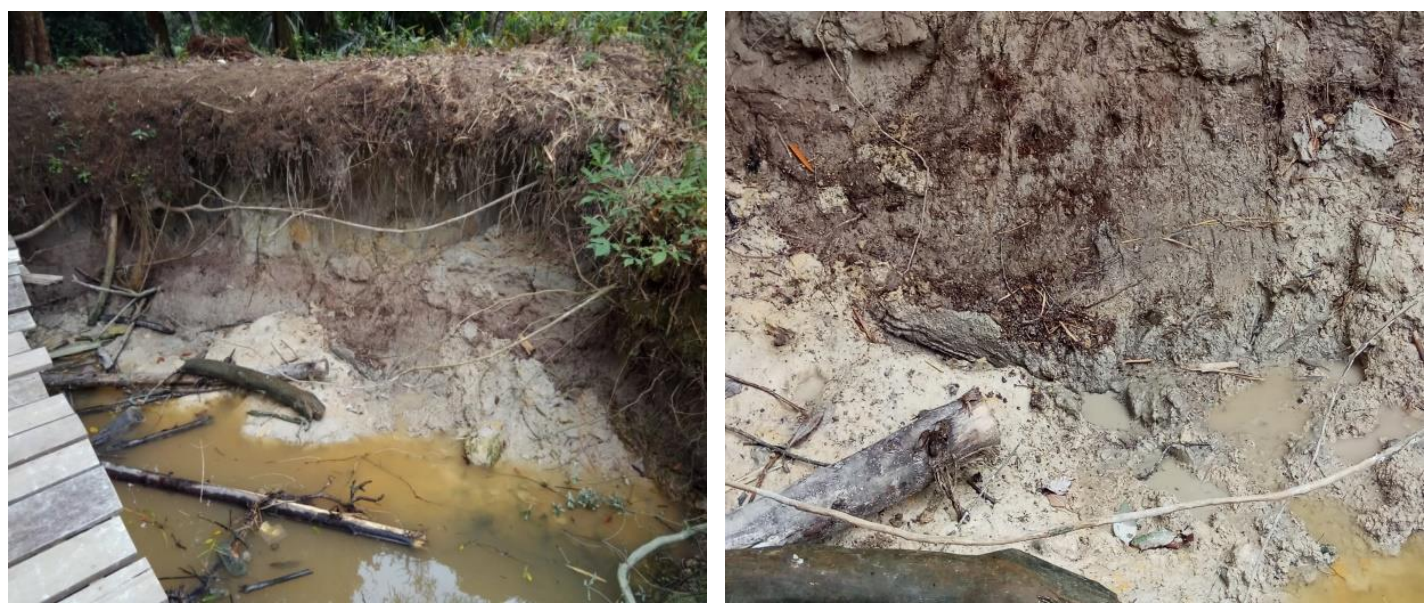

Gambar 2. Proses erosi Tebing Sungai Siak

Salah satu faktor yang mempengaruhi terjadinya erosi pada bantaran sungai siak adalah kuat arus dan gelombang akibat aktifitas transportasi masyarakat seperti terlihat pada

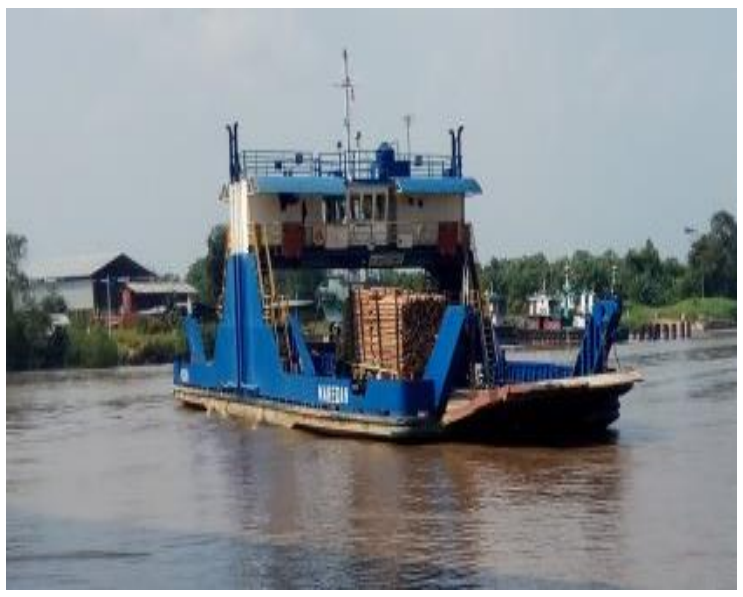

gambar 3. Sehingga memperparah tingkat erosi dan pengikisan tanah pada tebing -tebing di sepanjang bantaran sungai siak kevamatan Tualang Kabupaten Siak.

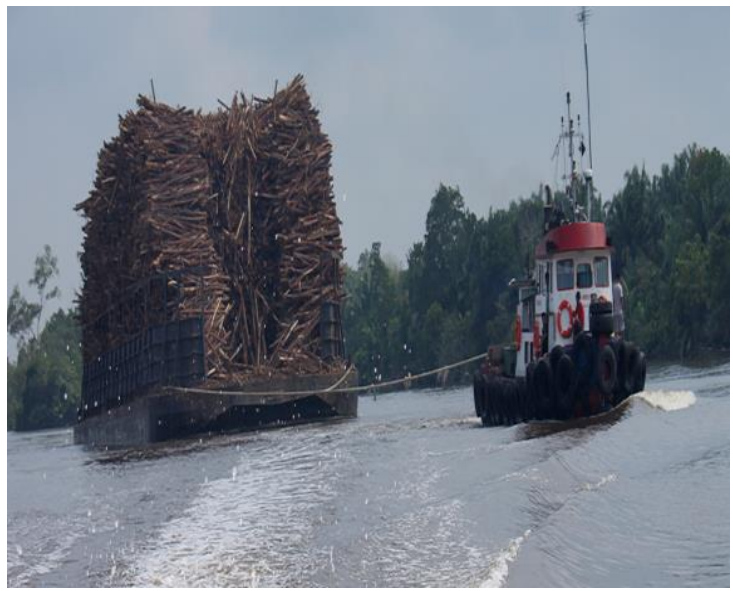

Gambar 3.Aktifitas Transportasi Air

Berdasarkan Informasi yang diperoleh dari Dinas Binamarga dan Pengairan Kabupaten siak bahwa pemerintah sudah melakukan penanganan dengan membangun dinding penahan tanah berupa Turap, Bronjong dan Concrete Reverment Mattress ( CRM) pada beberapa tempat yang tingkat abrasinya tinggi serta berdekatan dengan lokasi pemukiman masyarakat. Hal ini diakibatkan oleh keterbatasan dana pemerintah dalam hal tersebut. Sehingga masih dirasa kurang optimal dalam penanggulangan abrasi yang terjadi di sepanjang bantaran sungai siak.

Pelebaran Sungai dan kerusakan 


\section{pelindung Alami sungai}

Pelebaran sungai dapat disebabkan oleh terjadinya alih fungsi lahan di sekitar bantaran sungai dari hutan bakau/Mangrove menjadi kebun sawit milik penduduk. Keberadaan Kebunsawit ini menyebabkan daya ikat tanah/lahan di sekitar bantaran sungai menjadi menurun sehingga proses erosi dapat terjadi dengan mudah. Erosi sungai dapat terjadi akibat ketidak stabilan suplay dan kehilangan sedimen sepanjang aliran sungai.

Menteri Lingkungan Hidup, 2005. Bantaran

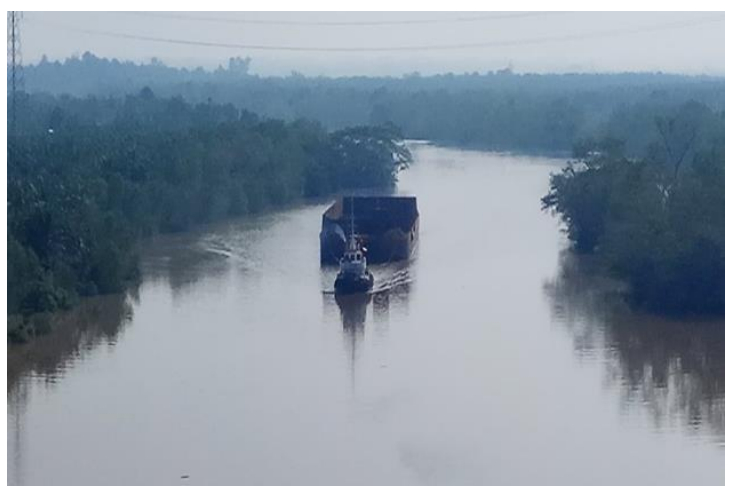

Sungai Siak telah mengalami kerusakan yang ditandai dengan semakin melebarnya badan sungai. Pada 20 tahun yang lalu tidak lebih dari $100 \mathrm{~m}$, sekarang sudah mencapai $150 \mathrm{~m}$. Lahan di bantaran sungai termasuk vegetasi diatasnya hilang tergerus gelombang yang disebabkan lalu lintas kapal bertonase tinggi. Kerusakan bantaran sungai juga disebabkan hilangnya green belt di pinggiran sungai yang disebabkan hempasan gelombang juga keracunan oleh bahan - bahan pencemar. Laju erosi tebing Sungai Siak sekitar 2 cm per hari seperti dapat dilihat pada gambar 4 .

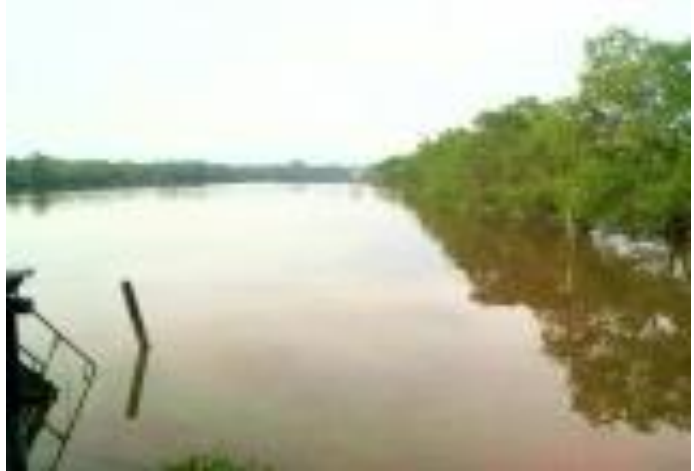

Gambar 4.Pelebaran Sungai Siak

Berdasarkan Kondisi tersebut pada beberapa lokasi bantaran sungai siak Kecamatan Tualang Kabupaten Siak, perlu dilakukan Penanaman Vegetasi tanaman Perlindung Bantaran Sungai sebagai upaya mencegah bertambahnya proses erosi di sekitar bantaran sungai, selain itu pelindung buatan juga diperlukan untuk menahan laju erosi di lokasi tersebut.

\section{Kerusakan Dinding Pengaman Tebing}

Hasil pengamatan di lapangan dari beberapa bangunan dinding penahan tanah yang ada di sepanjang bantaran sungai Siak Kecamatan Tualang Kabupaten Siak mengalami kerusakan dan penurunan fungsi layanan. Hal ini dapat dilihat pada gambar 5 dan gambar 6 terdapat permasalahan pada dinding penahan tanah tipe Bronjong . 


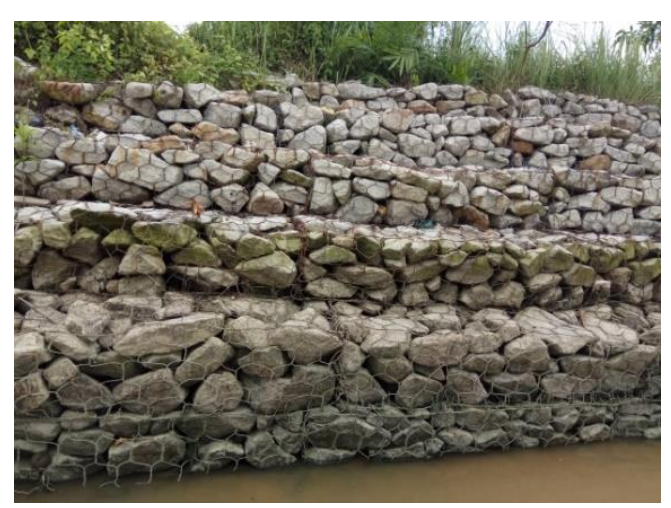

Gambar 5.Kondisi Awal Bangunan Brojong
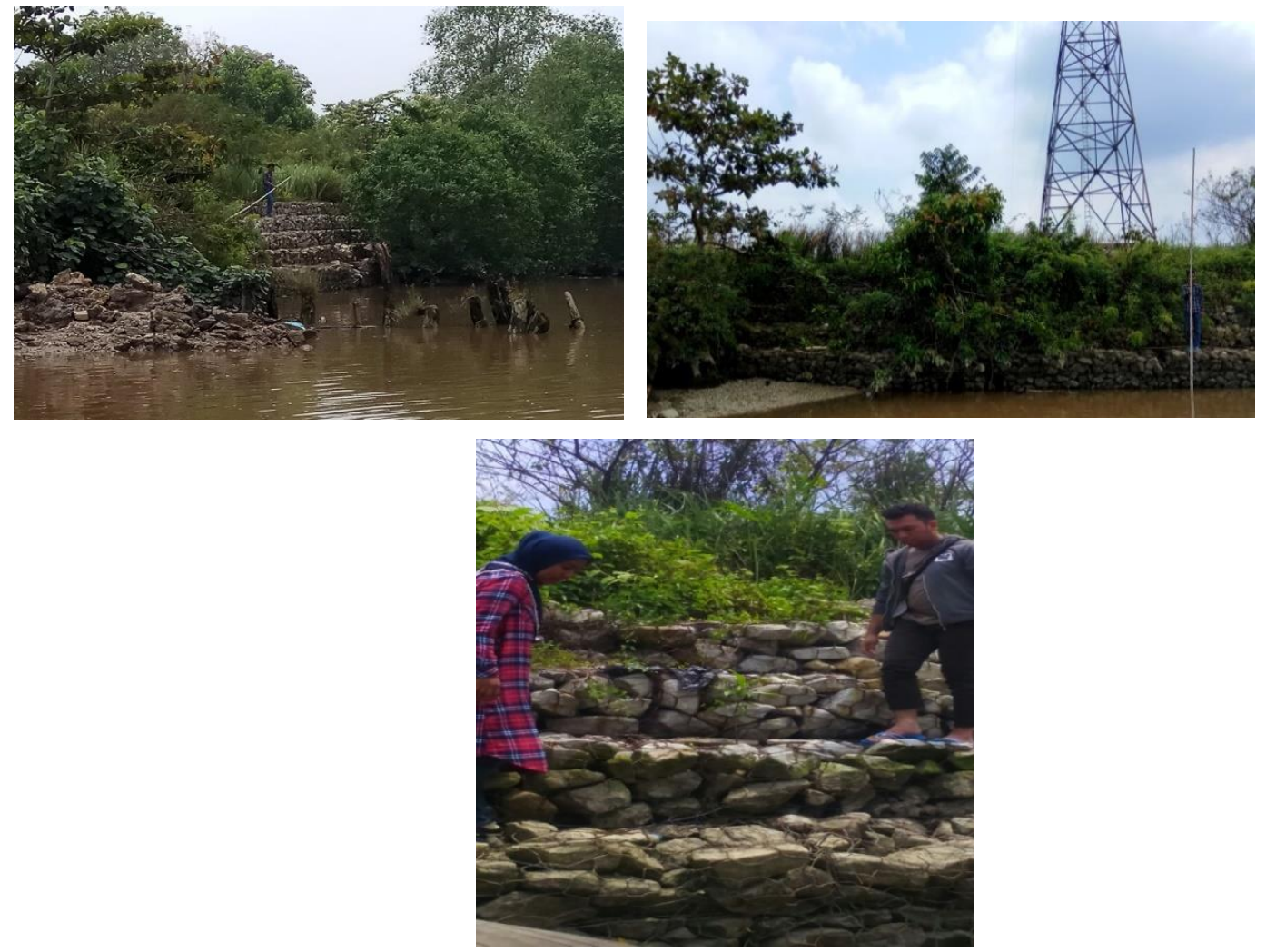

Gambar 6. Kerusakan pada Bangunan Brojong

Berdasar kondisi di lapangan banyak ditemukan kawat pembungkus bangunan bronjong yang patah dan lepas akibat kawat besi mengalami korosi sehingga berkarat dan akhirnya patah, hal ini disebabkan kondisi bronjong yang terendam air sungai dan mengalami pasang surut. Pada beberapa lokasi bronjong banyak ditumbuhi vegetasi tanaman bakau sehingga dapat merusak susunan pada Brojong tersebut. Kerusakan juga terjadi pada dinding penahan tanah tipe Concrete Reverment Matress (CRM), hasil pengamatan dilapangan menunjukan terjadinya kerusakan dibeberapa lokasi seperti dapat dilihat pada gambar 7 dan gambar 8 . 


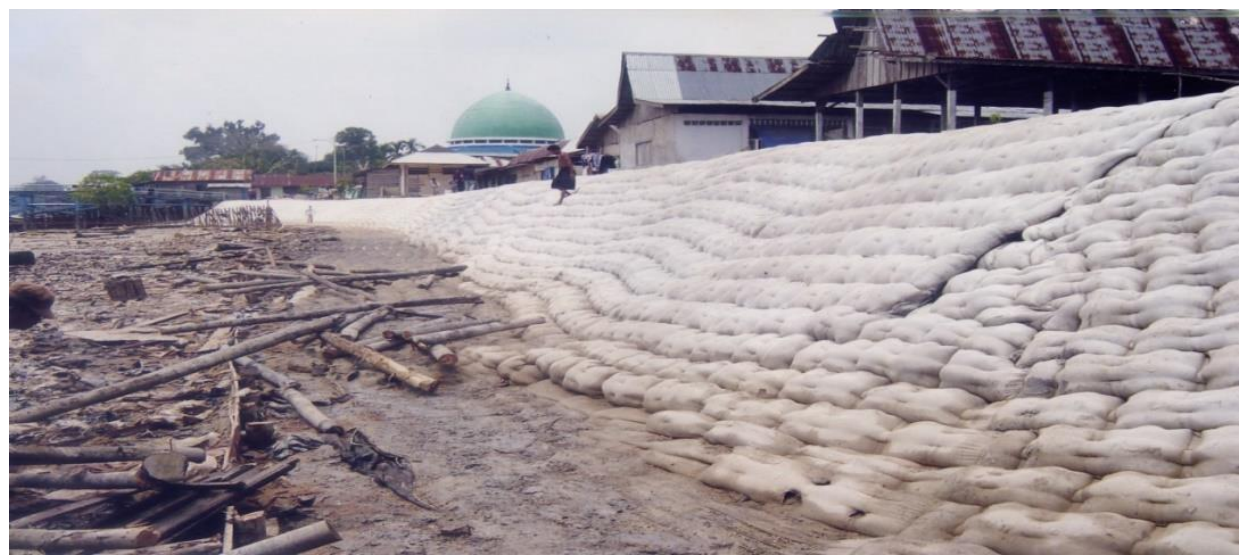

Gambar 7. Kondisi Awal Concrete Reverment Matress (CRM)
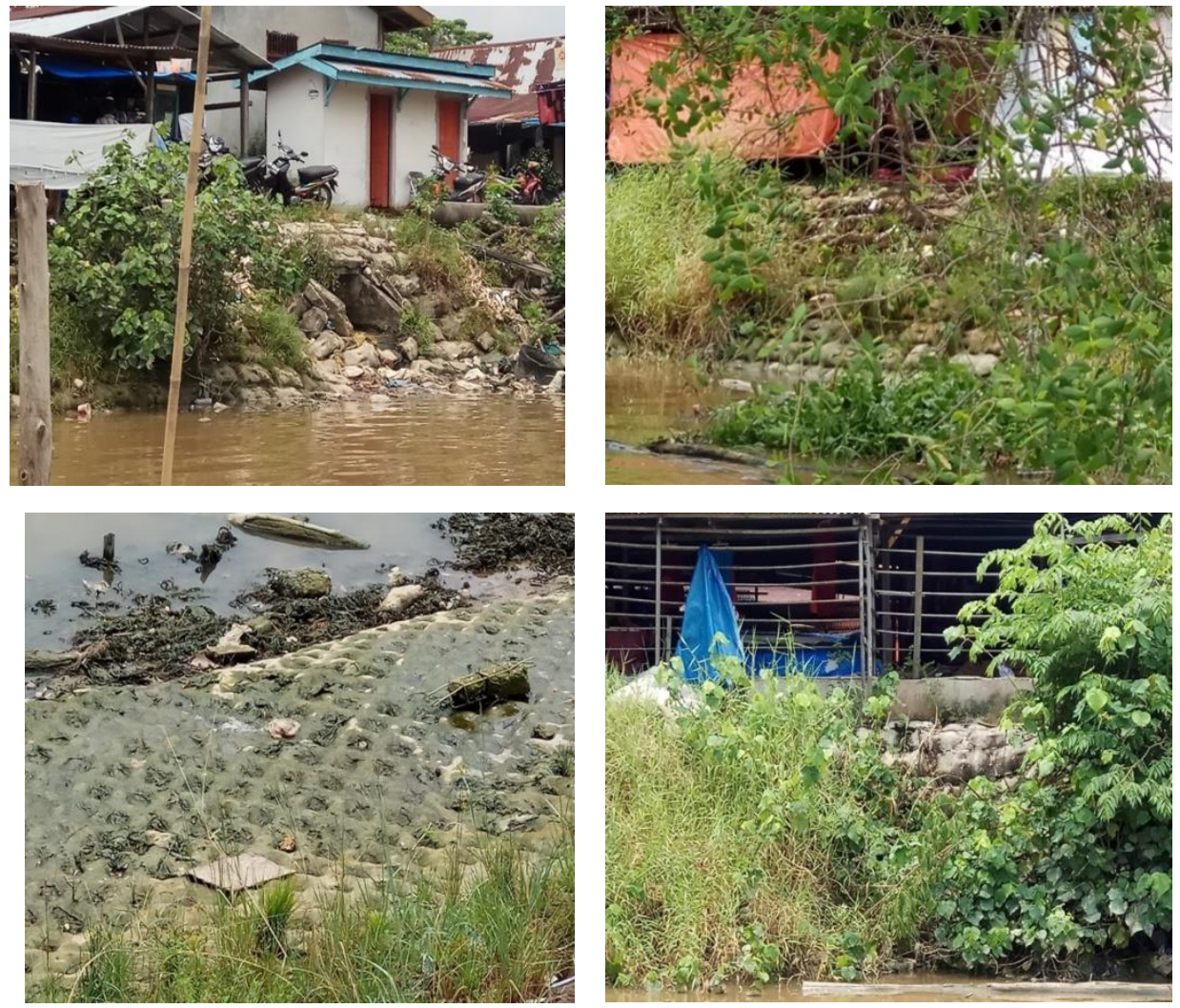

Gambar 8. Kerusakan yang Terjadi Pada Concrete Reverment Matress (CRM)

Berdasarkan kondisi dilapangan banyak ditemukan Concrete Reverment Matress (CRM) mengalami pengelupasan lapisan geotektil dan pengeroposan pada sisi dalam bangunan Concrete Reverment Matress (CRM), serta banyaknya tumbuhan baik lumut maupun vegetasi tumbuhan lain sehingga mempercepat terjadinya kerusakan. hal ini disebabkan kondisi
Concrete Reverment Matress (CRM) yang terendam air sungai dan mengalami pasang surut serta kualitas air yang banyak mengandung minyak lemak dengan kandungan sulfat, klhorida dan phosfat yang tinggi sehingga mempercepat perkembang biakan vegetasi tanaman bakau seperti Lythraceae dan Combretaceae sehingga dapat merusak dinding penahan tanah tipe 
Concrete Reverment Matress (CRM) tersebut.

\section{KESIMPULAN DAN SARAN}

\section{Kesimpulan}

Kondisi Bantaran Sungai Siak Kecamatan Tualang Kabupaten Siak Menunjukkan tingkat Kerusakan yang cukup tinggi baik pada bantaran sungai yang alami maupun yang telah diberikan pengaman tebing. Beberapa lokasi mengalami proses abrasi dan erosi terutama pada daerah yang masih alami.

Kerusakan Bantaran Sungai siak diakibatkan oleh faktor alam dan faktor antropogenik. Faktor alami dapat berupa kuat arus dan gelombang yang diakibatkan oleh aktifitas trasportasi masyarakatdan pabrik di sekitar lingkungan Sungai Siak. Sehingga dapat mengakibatkan abrasi, kerusakan ekosistem, dan kerusakan bangunan pengaman tebing. Sedangkan Faktor Antropogenik dalah perilakuk masyarakat dan Pabrik disekitar Sungai siak yang tidak memetuhi peraturan daerah dan kaidah yang berlaku.

\section{Saran}

Perlu adanya penelitian lebih lanjut tentang kondisi tanah dan kestabilan lereng pada lokasi disepanjang bantaran sungai siak, sehingga dapat merencanakan tipe dinding penahan tanah yang sesuai dengan kondisi didaerah tersebut.

\section{UCAPAN TERIMAKASIH}

Penulis mengucapkan terima kasih kepada pihak-pihak yang telah membantu dalam pelaksanaan Penelitian Dosen Pemula terutama kepada Kementrian Riset, Teknologi, dan Pendidikan Tinggi. semoga dengan hasil
Penelitian ini dapat membantu dalam perencanaan Bangunan air dan penanganan Erosi di Kecamatan Tualang.

\section{DAFTAR PUSTAKA}

Anwar, M Ruslin.Pudyono and M, Sahiruddin. (2009). Penanggulangan Erosi Secara Struktural pada aliran Sungai Bango. Jurnal Rekayasa Teknik Sipil, 3(1), 51-63.

Antaranews.com. (2017). Sungai Siak Mengalami Abrasi Satu Meter Pertahun, Aviable from http://www.antaranews.com/berita/509 306/sungai-siak-alami-abrasi-satumeter-pertahun, Accesed : 2017, Maret 30.

Asdak, C. (2007). Hidrologi dan Pengelolaan Daerah Aliran Sungai. Yogyakarta: Gajah Mada University Press.

Beauvais, M., Pellerin, S., Dubé, J., \& Lavoie, C. (2017). Herbarium specimens as tools to assess the impact of large herbivores on plant species. Botany, 95(2), 153-162. doi:10.1139/cjb-2016-0206.

Das, Braja, M. (1993). Mekanika Tanah (Prinsip-prinsip Rekayasa Geoteknis), Edisi Ketiga. Jakarta: Erlangga.

Hardiyatmo H.C. (1992). Mekanika Tanah II, Edisi Kelima. Yogyakarta: Gajah Mada University Press.

Infosiak.com. (2015). Selamatkan Sungai Siak, Alfedri:Hentikan Izin Pabrik Sepanjang Sungai Siak, Aviable from 
https://www.infosiak.com/birokrasi/sela

mat-sungai-siak-alfedri-hentikan-izin-

pabrik-sepanjang-sungai/, Accesed :

2015, Februari 17.

Iskandar.J and Dahiyat. Y. (2012).

Keanekaragaman Ikan Di Sungai Siak

Riau. Bionatura-Jurnal Ilmu-Ilmu

Hayati dan Fisik. 14(1). 51-58.

Gholo. K.B. (2014). Evaluasi Perkuatan Tebing

Sungai Sukun di Kepanjen. Skripsi Fakultas

Teknik Universitas Tribhuwana Tunggadewi.

Lihawa.F.,Patuti.I.M,.Nurfaika. (2014).

Sebaran Aspek Keruangan Tipe

Longsoran Didaerah Aliran Sungai Alo

Provinsi Gorontalo (Spread of Spatial

Aspect of Landslide Types at Alo

Watershed in Gorontalo Province),

Jurnal Manusia dan Lingkungan, 21(3).

Teknik Sipil, Maret 2016.

Rosihun.M, Endaryanta. (2011). Analisis

Stabilitas Talud Bronjong Uin Sunan

Kalijaga Yogyakarta. Jurnal INERSIA, 7(2), 162-201.

Zainal, R. (2005). Kebijakan Pemerintah

Propinsi Riau Dalam Pengelolaan DAS.

Prosiding Seminar Penyelamatan Dan

Pelestarian Daerah Aliran Sungai Siak.

Unri Press, Pekanbaru.
November 2014:277-285

Naditia.J. (2011). Evaluasi Ekonomi Ekosistem Sungai (Studi Kasus: Sungai Siak. Kota Pekanbaru, Provinsi Riau). Skripsi Institut Pertanian Bogor, Bogor. Putra. (2010). Analisis Stabilitas Lereng Pada Badan jalan dan Perencanaan Perkuatan Dinding Penahan Tanah. Jurnal Teknik Sipil, 14(1), januari 2010.

Rahim. (2000). Pengendalian Erosi Tanah Dalam Rangka Pelestarian Lingkungan Hidup. Jakarta: PT. Bumi Aksara.

Ramdhani. (2010). Analisis Stabilitas Lereng Akibat Beban Gempa Dengan perkuatan Dinding Penahan Tanah Menggunakan Softwere di Desa Tambankmerang Girimarto Wonogiri. e-Journal Matriks

- How to cite this paper :

Soehardi, F., \& Dinata, M. (2018). Identifikasi Kerusakan Dinding Penahan Tanah Sungai Siak (Studi Kasus Kecamatan Tualang Kabupaten Siak). Jurnal Teknik Sipil Unaya, 4(2), 40-50. 